\title{
Nitrogen during the establishment period of Mombasa grass
}

\section{Nitrogênio em períodos do estabelecimento de capim Mombaça}

\author{
Marcio Odilon Dias Rodrigues ${ }^{1 *}$; Antonio Clementino dos Santos ${ }^{2}$; \\ Marcos Odilon Dias Rodrigues ${ }^{1}$; Otacilio Silveira Junior ${ }^{1}$; \\ Luciano Fernandes Sousa²; Ana Flávia Gouveia de Faria ${ }^{3}$
}

\begin{abstract}
The aim of this study was to investigate the effect of nitrogen $(\mathrm{N})$ concentration during the establishment period of Mombasa grass (Panicum maximum Jacq.). The experiment was conducted using four different $\mathrm{N}$ concentrations $(0,30,60$ and $90 \mathrm{~kg} \mathrm{~N} / \mathrm{ha})$ during the establishment period in order to evaluate the effect of nitrogen on the plant. These effects were assessed using different indexes, including the efficiency of nitrogen use and agricultural, physiological and nutritional efficiencies. We also determined the total dry matter and nitrogen accumulation in the plant. The recovery of applied $\mathrm{N}$ and the agronomic efficiency of Mombasa grass were found to be greater with increasing $\mathrm{N}$ concentrations, and all indexes tested were found to be affected by the concentration of applied N. Based on the indexes studied, $90 \mathrm{~kg} \mathrm{~N} / \mathrm{ha}$ was found to be most suitable for Mombasa grass during the establishment period.
\end{abstract}

Key words: Agronomic efficiency. Nitrogen fertilizer. Panicum maximum Jacq. Nitrogen recovery.

\section{Resumo}

O presente trabalho teve como objetivo estudar o efeito de doses de nitrogênio $(\mathrm{N})$ em pasto de capimMombaça (Panicum maximum Jacq.) durante o período de estabelecimento. Foi realizado experimento com quatro doses de $\mathrm{N}\left(0,30,60,90 \mathrm{~kg} \cdot \mathrm{ha}^{-1}\right)$, durante o período de estabelecimento, para avaliação do efeito do nitrogênio na planta, através de índices de eficiência de utilização, eficiência agronômica, fisiológica e nutricional, avaliou-se ainda a matéria seca total e o acúmulo de nitrogênio na planta. Concluiu-se que a recuperação do $\mathrm{N}$ aplicado e a eficiência agronômica pelo capim Mombaça aumentou com o incremento das doses. Sendo que, para todos os índices ocorreu influência das doses aplicadas. A dose de $90 \mathrm{~kg}$ de N.ha-1 ${ }^{-1}$ com base nos índices estudados, é a mais indicada para o período de estabelecimento do capim-Mombaça.

Palavras-chave: Eficiência agronômica. Adubo nitrogenado. (Panicum maximum Jacq.). Recuperação do $\mathrm{N}$ aplicado.

1 Discentes de Doutorado, PPGCat, Universidade Federal do Tocantins, UFT, campus Araguaína, TO, Brasil. E-mail: marciozoouft@hotmail.com; marcosodilon22@gmail.com; otaciliosilveira@hotmail.com

2 Profs., UFT, Campus Araguaína, TO, Brasil. E-mail: clementino@uft.edu.br; luciano.sousa@uft.edu.br

3 Prof ${ }^{a}$, Universidade Estadual do Tocantins, UNITINS, Campus Palmas, TO, Brasil. E-mail: flaviazootec@hotmail.com

Author for correspondence 


\section{Introduction}

Nitrogen (N) application promotes the production of green and dry matter, sward height, dry matter accumulation rate and the number of tillers. Therefore, $\mathrm{N}$ fertilization directly contributes to $\mathrm{N}$ accumulation in the plant, whereby the amount of nitrogen accumulated in the tissues increases with application of higher concentrations of $\mathrm{N}$, demonstrating the contribution of $\mathrm{N}$ in the soil (CASTAGNARA et al., 2011).

Proper pasture stabilization during the establishment period is essential in order to maintain the forage vigor during subsequent cycles, leading to productive and vigorous tillers. However, this requires an optimized $\mathrm{N}$ supply, as this is a factor which affects tiller growth and development processes and enables biomass accumulation for carbon fixation. It is known that $\mathrm{N}$ is an important component of proteins including chlorophyll, which is essential for photosynthetic processes, and therefore, forage production (ALEXANDRINO et al., 2010). Newly established developing tissues require larger quantities of $\mathrm{N}$ for intensive cell division and protein production (CALOT et al., 1984).

The use of nitrogen in tropical pastures is important in order to maintain productivity, especially due to the intensive forage mass flow during the rainy season. However, the inappropriate use of fertilizers makes them potential environment polluters. When combined with several other factors including climate, soil and plants, in addition to interactions between these factors, fertilizers can interfere with the nutrient absorption and utilization of plants through leaching and denitrification processes, reducing the fertilization efficiency (ESPINDULA et al., 2010).

The recovery of applied nitrogen in perennial tropical forages can reach up to $90 \%$, in which there is a linear decrease with increasing concentrations of applied N. Because of this, fertilization management should ensure maximum efficiency of nutrient use by the plant (GUELFI-SILVA et al., 2011). Fertilization strategies during the establishment period should be optimized for the maximum conversion of applied $\mathrm{N}$ into forage mass, such that the system reaches the maximum use of applied $\mathrm{N}$.

Studies in the literature which have evaluated the use of nitrogen sources have primarily focused on the period following pasture establishment, with less importance given to the establishment period. Nonetheless, the initial tiller growth and development period is fundamental for good sward establishment. Therefore, the aim of this study was to evaluate the effect of the $\mathrm{N}$ concentration of fertilizer in Mombasa grass, focusing on several efficiency indexes regarding the use of nitrogen.

\section{Materials and Methods}

This study was conducted between December 2014 and February 2015 in Araguaina (Tocantins, Brazil), at the Federal University of Tocantins. The experimental area was located at the geographical coordinates $7^{\circ} 6^{\prime} 16^{\prime \prime} \mathrm{S} 48^{\circ} 12^{\prime} 3^{\prime \prime} \mathrm{W}$. The climate is classified as Aw (hot and humid), with welldefined seasons, an average annual precipitation of $1800 \mathrm{~mm}$ and temperature of $25^{\circ} \mathrm{C}$. The soil within the experimental area was classified as Quartzipsamment soil.

The study was carried out during the 60 days after pasture germination of Mombasa grass. This included the establishment period, which began on 18 December 2014 (day 15 after germination) and finished on 1 February 2015, totaling an evaluation period of 45 days.

Mombasa seeds of the Panicum Maximum cv. were used for seeding, which was performed on 27 November 2014. The seeding process used $3 \mathrm{~kg} / \mathrm{ha}$ of viable pure seeds with 34 pure live seeds, a purity of $40 \%$ and minimum germination of $80 \%$. The treatments applied included four different $\mathrm{N}$ concentrations $(0,30,60$ and $90 \mathrm{~kg}$ $\mathrm{N} / \mathrm{ha}$ ) in a complete randomized block design 
with six replicates, totaling 24 experimental units. Superphosphate application was carried out during seeding to raise the $\mathrm{P}$ content to $20 \mathrm{mg} \mathrm{dm}^{-3}$. Fifteen days after germination, $\mathrm{KCl}$ was applied to raise the $\mathrm{K}$ content to $30 \mathrm{mg} \mathrm{dm}^{-3}$, as well the addition of the nitrogen-containing fertilizer $\left(\left(\mathrm{NH}_{4}\right)_{2} \mathrm{SO}_{4}\right)$. The nitrogen source included $21 \% \mathrm{~N}$ and $24 \% \mathrm{~S}$, characterizing the source as a compound fertilizer. the chemistry of the soil is presented in the table 1.

The forage samples were collected at the end of the cycle ( 45 days) with the aid of an iron square of $0.5 \mathrm{~m}^{2}(1 \times 0.5 \mathrm{~m})$, and the material was harvested $35 \mathrm{~cm}$ from the soil surface. Subsequently, in the laboratory, a subsample of approximately $300 \mathrm{~g}$ was separated into its components, including the leaves, stems and other material. The components were weighed and then dried in a forced ventilation oven at $65^{\circ} \mathrm{C}$ for 72 hours to obtain the dry matter (QUEIROZ; SILVA, 2002). The total dry matter $(\mathrm{kg} / \mathrm{ha})$ was used to generate the indexes. The samples were then ground and packed in plastic bags. The gross forage production rate $(\mathrm{kg} / \mathrm{ha} /$ day $)$ was determined over the following three periods of the tiller: first period (T1; day 16 to 30 after germination); second period (T2; day 31 to 45 after germination); and third period (T3; day 46 to 60 after germination). The maximum temperature and accumulated precipitation during the evaluation period are shown in Figure 1.

Table 1. Chemical characteristics of the soil prior to maintenance fertilization and treatments, over the year in which the experiment was conducted.

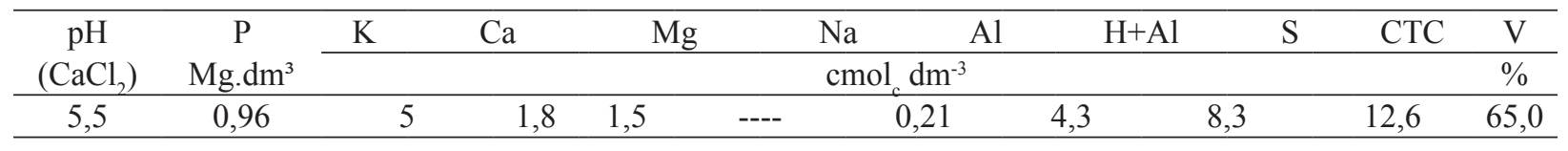

Figure 1. Weekly maximum temperature and accumulated rainfall during the experimental period.

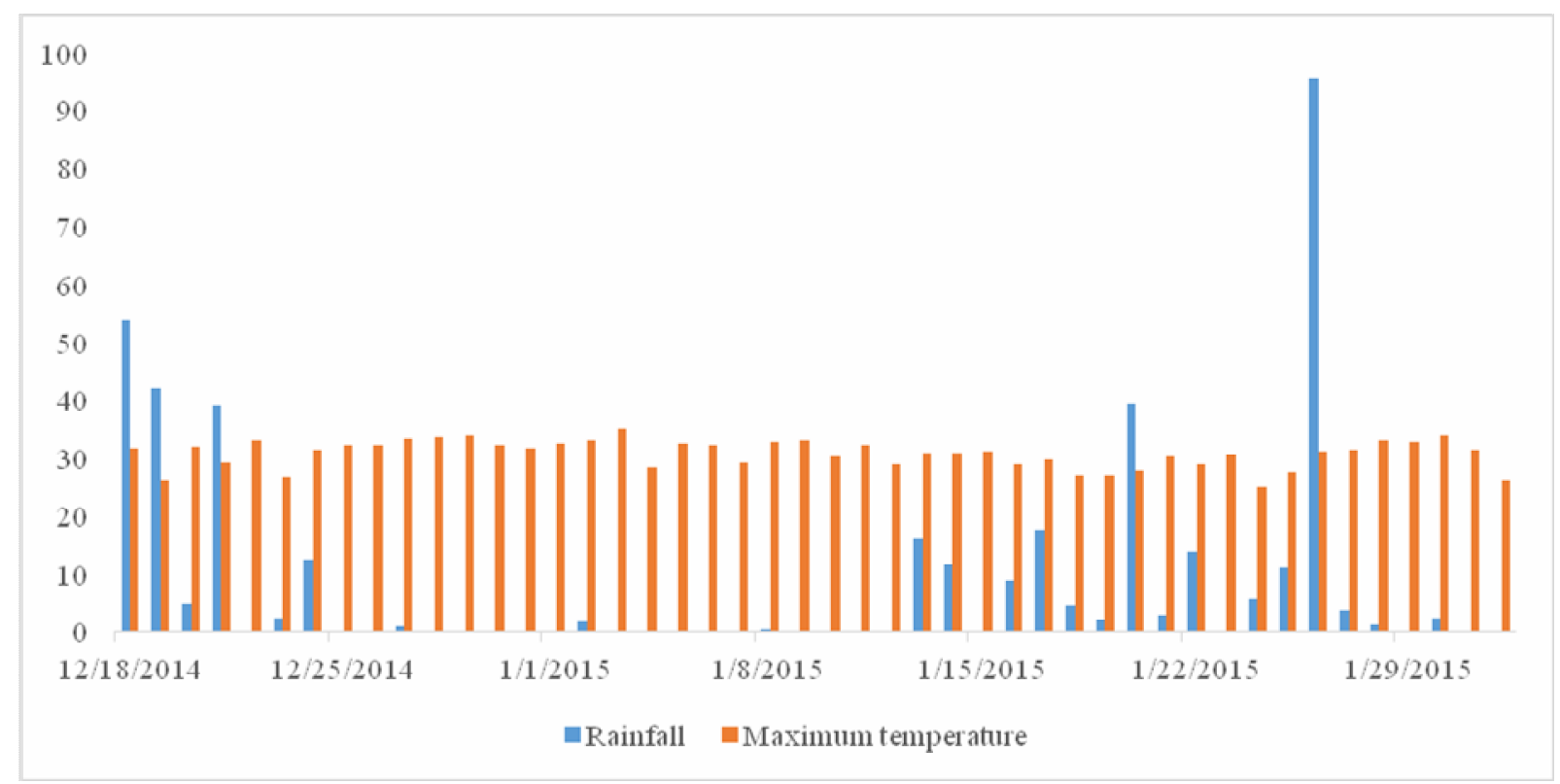


We performed chemical analyses of the foraging material sampled to obtain the total $\mathrm{N}$ content during the trial period, according to the methodology described by Malavolta et al. (1997). The values for $\mathrm{N}$ accumulation were obtained from the $\mathrm{N}$ content of the plant tissues and the dry matter (DM) produced. Using the DM and $\mathrm{N}$ accumulation data, the following indexes were calculated:

Nitrogen utilization efficiency $(\mathbf{N U E})=($ total dry matter $\left(\mathrm{kg}^{2}\right) / \mathrm{N}$ accumulation $\left.(\mathrm{g})\right)$ in $(\mathrm{kg}$ of $\mathrm{DM})^{2} / \mathrm{g}$ of $\mathrm{N}$ accumulation (SIDDIQI; GLASS, 1981).

\section{Recovery of nitrogen applied (RNA) =} $(\mathrm{N}$ accumulation $(\mathrm{kg})$ with fertilization $-\mathrm{N}$ accumulation $(\mathrm{kg})$ without fertilization) / (N concentration applied $(\mathrm{kg}) \times 100)$. Results are expressed as a percentage (FAGERIA, 1998).

Agronomic efficiency of nitrogen applied $(\mathbf{A E})=($ dry mass with fertilization $(\mathrm{kg})-$ dry mass without fertilization $(\mathrm{kg})$ ) / $\mathrm{N}$ concentration. Results are expressed as $\mathrm{kg}$ of $\mathrm{DM} / \mathrm{kg}$ of $\mathrm{N}$ applied (FAGERIA, 1998).

Physiological efficiency $(\mathrm{PE})=($ dry mass with fertilization $(\mathrm{kg})$ - dry mass without fertilization $(\mathrm{kg}))$ / ( $\mathrm{N}$ accumulation with fertilization $(\mathrm{kg})-\mathrm{N}$ accumulation without fertilization $(\mathrm{kg})$ ). Results are expressed as $\mathrm{kg}$ of $\mathrm{DM} / \mathrm{kg}$ of $\mathrm{N}$ accumulated (FAGERIA, 1998).

Loss of nitrogen applied (LNA) $=(\mathrm{N}$ accumulated $(\mathrm{kg}) \times 100) /$ concentration of $\mathrm{N}$ applied. The results are expressed as a percentage.

For the statistical analysis of the data a repeated measures analysis of variance (ANOVA) was performed to separately analyze the behavior of each of the variables over time (three times) relative to the tested treatments. The repeated measures ANOVA was used to identify the moments that differed in order to determine whether there was a statistical difference between the $\mathrm{N}$ concentrations over time. Results were considered statistically significant at the 5 and/or $1 \%$ significance level. The time period was not considered as a factor for the nitrogen use efficiency variables, therefore, a regression analysis model was used for these variables to test their suitability in linear and quadratic models.

\section{Results and Discussion}

The results for RNA, NUE, LNA, NAT, TDM, $\mathrm{AE}$ and $\mathrm{PE}$ are presented in Table 2.

There was an increasing linear effect on RNA with increasing $\mathrm{N}$ concentrations $(\mathrm{P}<0.05$; Table 2$)$. This demonstrates the positive effect of fertilization up to the maximum concentration evaluated (90 $\mathrm{kg} \mathrm{N} / \mathrm{ha}$ ). At $90 \mathrm{~kg} \mathrm{~N} / \mathrm{ha}$ we observed RNA values which were 34.96 and $9.26 \%$ higher than the $\mathrm{N}$ concentrations of 30 and $60 \mathrm{~kg} \mathrm{~N} / \mathrm{ha}$, respectively. The lowest value was $32 \%$ (30 kg N/ha), showing the positive effect of fertilization during the pasture establishment period, which continued to increase up to the maximum dose. The RNA values ranged from 30 to $68.2 \%$, as shown in Table 2 .

It should be noted that the $\mathrm{N}$ concentration of the applied fertilizer contributed to the increase in RNA with higher $\mathrm{N}$ concentrations (Table 2). The concentrations used did not exceed the limit of 100 $\mathrm{kg} \mathrm{N} / \mathrm{ha}$, as based on a previous study (CANTO et al., 2013) $\mathrm{N}$ application at concentrations greater than $90 \mathrm{~kg} \mathrm{~N} / \mathrm{ha}$ during the establishment period negatively affects the recovery of applied $\mathrm{N}$.

The NUE was affected by the $\mathrm{N}$ concentration $(\mathrm{P}<0.05)$, where the NUE values for accumulated $\mathrm{N}$ ranged between 0.0767 and $0.0312 \mathrm{~kg}$ of $\mathrm{DM}$ $\mathrm{g}^{-1}$ for the $\mathrm{N}$ concentrations of 0 and $90 \mathrm{~kg} \mathrm{~N} / \mathrm{ha}$, respectively (Table 2). 
Table 2. Recovery of nitrogen applied (RNA; \%), nitrogen use efficiency (NUE; kg/g), loss of nitrogen applied (LNA; $\%$ ), nitrogen accumulation in the tissues (NAT; kg/ha), total dry matter (TDM; kg/ha), agronomic efficiency (AE; $\mathrm{kg}$ of DM/kg of $\mathrm{N}$ applied), physiological efficiency (PE; $\mathrm{kg} / \mathrm{kg}$ ), total dry matter (TDM; $\mathrm{kg} / \mathrm{ha} / \mathrm{day}$ ) and gross forage production rate $(\mathrm{kg} / \mathrm{ha} /$ day) of Mombasa grass treated with fertilizer at a concentration of either $0,30,60 \mathrm{and} 90 \mathrm{~kg}$ N/ha.

\begin{tabular}{|c|c|c|c|c|c|c|c|}
\hline \multirow{3}{*}{ Variable } & & \multicolumn{4}{|c|}{ Treatments } & \multirow{3}{*}{ Equations } & \multirow{3}{*}{$\mathrm{R}^{2}$} \\
\hline & & 0 & 30 & 60 & 90 & & \\
\hline & & \multicolumn{3}{|c|}{ kg de N.ha ${ }^{-1}$} & & & \\
\hline RNA & & $\begin{array}{l}--- \\
---\end{array}$ & 30,64 & 55,94 & 65,60 & $\mathrm{y}=15,779+0,5826 \mathrm{~N}$ & 0,84 \\
\hline NUE & & 0,076 & 0,058 & 0,039 & 0,031 & $\mathrm{y}=0,0762+0,0005 \mathrm{~N}$ & 0,81 \\
\hline LNA & & ---- & 67,951 & 41,48 & 28,25 & $\mathrm{y}=67,951+0,4411 \mathrm{~N}$ & 0,68 \\
\hline NAT & & 0,924 & 21,06 & 41,19 & 61,32 & $\mathrm{y}=0,9241+0,6712 \mathrm{~N}$ & 0,89 \\
\hline MST & & 265,62 & 831,39 & 1396,9 & 1962,9 & $y=265,62+18,859 N$ & 0,90 \\
\hline EA & & ---- & 15,54 & 17,21 & 18,871 & $\mathrm{y}=13,876+0,0555 \mathrm{~N}$ & 0,81 \\
\hline $\mathrm{PE}$ & & ---- & 47,23 & 36,91 & 26,59 & $\mathrm{y}=57,56+0,3441 \mathrm{~N}$ & 0,85 \\
\hline TDM & & 10,61 & 33,24 & 55,61 & 78,50 & $\mathrm{y}=10,61+0,7544 \mathrm{~N}$ & 0,87 \\
\hline \multirow{3}{*}{ TPBF } & $1^{\mathrm{o}}$ & $33,53 \mathrm{Ad}$ & $43,89 \mathrm{Bc}$ & $54,26 \mathrm{Bb}$ & $64,63 \mathrm{Ba}$ & $\mathrm{y}=33,533+0,3456 \mathrm{~N}$ & 0,61 \\
\hline & $2^{\circ}$ & $15,56 \mathrm{Bd}$ & $28,29 \mathrm{Cc}$ & $41,03 \mathrm{Cb}$ & $53,76 \mathrm{Ca}$ & $\mathrm{y}=15,567+0,4244 \mathrm{~N}$ & 0,79 \\
\hline & $3^{\circ}$ & $1,333 \mathrm{Cd}$ & $89,80 \mathrm{Ac}$ & $178,66 \mathrm{Ab}$ & $267,28 \mathrm{Aa}$ & $\mathrm{y}=1,3333+2,9556 \mathrm{~N}$ & 0,93 \\
\hline
\end{tabular}

A lower nitrogen use efficiency was observed at $90 \mathrm{~kg} \mathrm{~N} / \mathrm{ha}$. In contrast to NUE, the DM forage production during the establishment period was negatively correlated with increasing $\mathrm{N}$ concentration (Table 2). This resulted in reduced yields at the lower $\mathrm{N}$ concentrations and, combined with the low $\mathrm{N}$ accumulation in the tissues (Table 2), accounted for the greater NUE observed at the lower $\mathrm{N}$ concentrations. This result suggests that the NUE does not reflect the real agronomic and nutritional status of the Mombasa grass pasture during the establishment period. Therefore, it is necessary to evaluate parameters other than NUE in order to better determine the effects of the $\mathrm{N}$ concentration of the fertilizer.

We observed the same trend for NUE and PE, where decreased NUE and PE values were associated with higher $\mathrm{N}$ concentrations in the fertilizer (Table 1). In contrast, Silva et al. (2011) reported that the highest $\mathrm{N}$ concentrations were associated with the greatest NUE, with increases in NUE of up to $140 \%$ in $\mathrm{N}$-fertilized areas compared to nonfertilized areas. However, as shown in Table 1, the plants accumulated less $\mathrm{N}$ in their tissues when the fertilizer contained lower $\mathrm{N}$ concentrations $(0$ and $30 \mathrm{~kg} \mathrm{~N} / \mathrm{ha}$ ), resulting in reduced DM production.

The values for NUE and PE were higher at lower $\mathrm{N}$ concentrations, possibly due to decreased $\mathrm{N}$ accumulation in the tissues. This strengthens the theory that during periods where nutrients are low, the plant can alter the development of morphological components to balance the low $\mathrm{N}$ concentration in the soil and tissues in order to meet its physiological activities, thereby achieving maximum efficiency of $\mathrm{N}$ use. However, as a result the DM production is directly affected (SILVA et al., 2011). It should be noted that plant growth is directly related to the $\mathrm{N}$ concentration in the tissues, and not only with total accumulated N. Plant development only occurs when there is a specific minimum $\mathrm{N}$ concentration in tissues, which differs between species (SIDDIQI; GLASS, 1981).

Based on the LNA index, $\mathrm{N}$ loss to the soil was 67.9 and $28.25 \%$ for the highest and lowest $\mathrm{N}$ concentrations of 90 and $30 \mathrm{~kg} \mathrm{~N} / \mathrm{ha}$, respectively, 
and the difference in LNA was $6.3 \mathrm{~kg}$. Therefore, it is evident that the efficiency of the plant to absorb $\mathrm{N}$ from the fertilizer was greatest when $\mathrm{N}$ was provided at concentrations higher than $30 \mathrm{~kg} \mathrm{~N} / \mathrm{ha}$.

We observed a significant increasing linear effect of NAT with $\mathrm{N}$ concentration $(\mathrm{P}<0.05$; Table 2), the opposite of that reported for NUE (Table 1). The NAT was higher with increasing N concentrations, with NAT values ranging between 3.86 and $62.86 \mathrm{~kg}$ of $\mathrm{N}$ accumulated for 0 and 90 $\mathrm{kg} \mathrm{N} / \mathrm{ha}$, respectively. Therefore, it is evident that the plant was efficient at accumulating $\mathrm{N}$ from the fertilizer, with accumulation of $59 \mathrm{~kg}$ of $\mathrm{N}$ for the 90 $\mathrm{kg} \mathrm{N} / \mathrm{ha}$, when compared to control.

Given the results discussed above, we observed a linear increase in $\mathrm{N}$ accumulation in plant tissues with higher fertilizer $\mathrm{N}$ concentrations. We report that higher $\mathrm{N}$ concentrations provided greater $\mathrm{N}$ accumulation in the plant tissues, with a linear increase observed for the highest concentration tested (90 kg N/ha), similar to that previously reported by Silva et al. (2011). Kuyumjian (2014) reported an increase in the $\mathrm{N}$ content of Mombasa grass with increasing $\mathrm{N}$ concentrations for three different nitrogen sources, including horn hoof flour, blood meal and urea. According to the authors, horn hoof flour provided the highest $\mathrm{N}$ concentration per unit of fertilizer.

A significant effect was observed between $\mathrm{AE}$ and $\mathrm{N}$ concentration during the establishment period of Mombasa grass $(\mathrm{P}<0.01$; Table 2$)$. We observed a linear increase in $\mathrm{AE}$ with increasing $\mathrm{N}$ concentrations $(\mathrm{P}<0.01)$. The AE values observed were $15.541,17.206$ and $18.871 \mathrm{~kg}$ of $\mathrm{DM} / \mathrm{kg}$ of $\mathrm{N}$ applied for concentrations of 30,60 and $90 \mathrm{~kg}$ of $\mathrm{N} /$ ha, respectively. We observed 17.64 and $8.82 \%$ greater $\mathrm{AE}$ for $90 \mathrm{~kg}$ of $\mathrm{N} / \mathrm{ha}$ compared to 30 and 60 $\mathrm{kg} \mathrm{N} /$ ha, respectively.

The increase in $\mathrm{N}$ levels during the establishment period resulted in greater mass accumulation by the plant, therefore, higher $\mathrm{N}$ concentrations resulted in more efficient forage mass production by the plant. This observation can be explained by the increased $\mathrm{N}$ accumulation in tissues with increasing concentrations, where the highest concentration of $\mathrm{N}$ (90 kg of $\mathrm{N} / \mathrm{ha}$ ) resulted in $65.66 \%$ higher $\mathrm{N}$ accumulation compared to $30 \mathrm{~kg}$ of $\mathrm{N} / \mathrm{ha}$. It is noteworthy that there was reduced $\mathrm{N}$ loss with the increment of $\mathrm{N}$ concentrations. The highest concentration tested (90 kg of N/ha) lost $28.25 \%$ of applied $\mathrm{N}$, whereas the $\mathrm{N}$ loss for 60 and $30 \mathrm{~kg}$ of $\mathrm{N} /$ ha was 41.4 and $67.9 \%$, respectively (Table 2).

In this study, the highest forage DM production was observed for the highest $\mathrm{N}$ concentration, which increased $\mathrm{AE}$ when compared with the lower $\mathrm{N}$ concentrations. Interestingly, this trend does not apply at $\mathrm{N}$ concentrations exceeding $100 \mathrm{~kg} / \mathrm{ha}$ (SILVA et al., 2011), which may be related to greater $\mathrm{N}$ loss at this concentration, making the conversion of $\mathrm{N}$ in the fertilizer less efficient (CABEZAS, 2011; CANTO et al., 2013).

As shown in Table 1, the values increased linearly with higher $\mathrm{N}$ concentrations. Therefore, during the establishment period, concentrations of up to $90 \mathrm{~kg} / \mathrm{ha}$ allowed for a linear increase in $\mathrm{AE}$ with increasing $\mathrm{N}$ concentrations. However, previous studies have shown reduced $\mathrm{AE}$ values when the concentration of $\mathrm{N}$ in the fertilizer was higher than $100 \mathrm{~kg} / \mathrm{ha}$ (SILVA et al., 2011; KUYUMJIAN, 2014). According to Canto et al. (2013) the conversion of $\mathrm{N}$ into forage was reduced by $20.2,40.5$ and $60.7 \%$ for $\mathrm{N}$ concentrations of 200,300 and $400 \mathrm{~kg} / \mathrm{ha}$, respectively, when compared to $100 \mathrm{~kg} / \mathrm{ha}$.

The forage mass is crucial for the agronomic efficiency index, and the DM quantity affects the final AE outcome. According to Cabezas (2011), the efficiency of $\mathrm{N}$ conversion into forage in maize, millet and sorghum was highest for corn, which produced $496.9 \mathrm{~kg}$ of $\mathrm{DM}$ per $\mathrm{kg}$ of $\mathrm{N}$ applied, while the AE of millet and sorghum were 361.9 and $186.1 \mathrm{~kg} / \mathrm{kg}$, respectively. However, according to the authors, the higher efficiency observed for corn was mainly due to the increased DM production during the study period, corroborating the results found in the current study. 
The PE was found to be influenced by the concentration of $\mathrm{N}$ applied to the soil (Table 2). We observed a decreasing linear effect $(\mathrm{P}<0.01)$ for $\mathrm{PE}$ with increasing $\mathrm{N}$ concentrations. The maximum $\mathrm{PE}$ value of $47.23 \mathrm{~kg}$ of $\mathrm{DM} / \mathrm{kg}$ of accumulated $\mathrm{N}$ was observed at the $\mathrm{N}$ concentration of $30 \mathrm{~kg} \mathrm{~N} / \mathrm{ha}$, followed by 60 and $90 \mathrm{~kg} \mathrm{~N} / \mathrm{ha}$, which had PE values of 36.914 and $26.591 \mathrm{~kg}$ of DM/ $\mathrm{kg}$ of accumulated $\mathrm{N}$, respectively. There was a decrease in PE values at 90 and $60 \mathrm{~kg} \mathrm{~N} /$ ha of 43.69 and $21.84 \%$, respectively, compared to $30 \mathrm{~kg}$ of $\mathrm{N} / \mathrm{ha}$. This can be explained by the inverse cumulative ratio of $\mathrm{N}$ in the tissues with increasing $\mathrm{N}$ concentrations when compared with PE (Table 2). Therefore, the higher physiological efficiency for lower $\mathrm{N}$ concentrations was mainly due to reduced $\mathrm{N}$ accumulation in the tissues. The accumulation of $\mathrm{N}$ in the tissues was highest for $90 \mathrm{~kg}$ of $\mathrm{N} / \mathrm{ha}$, relative to 65.66 and $32.83 \%$ accumulation observed at the concentrations of 30 and $60 \mathrm{~kg}$ of $\mathrm{N} / \mathrm{ha}$, respectively. This demonstrates the inverse relationship of the PE index with NAT (Table 2).

We observed differences in gross forage production rate (GFPR) over the different evaluation periods $(\mathrm{P}<0.01)$ and for the different concentrations of $\mathrm{N}$ in the fertilizer $(\mathrm{P}<0.01$; Table 2). In the regression model we observed an increasing linear effect over the three periods.

There was a significant interaction between the $\mathrm{N}$ concentrations tested and the tiller lifespan $(\mathrm{P}<0.01)$. With increasing tiller lifespan, the GFPR observed during T3 varied with higher N concentrations, with values of $61.5,137.63$ and $213.52 \mathrm{~kg} / \mathrm{ha} /$ day for $\mathrm{N}$ concentrations of 30,60 and $90 \mathrm{~kg} / \mathrm{ha}$, respectively, when compared to T2. However, for the $0 \mathrm{~kg} / \mathrm{ha}$ concentration there was a reduction in GFPR of $14.23 \mathrm{~kg} / \mathrm{ha}$ /day during T3 when compared to T2. When fertilization was performed, the GFPR followed the same trend during the three evaluated periods, with a lower GFPR observed during T2 compared to T1 and T3. However, fertilization did not reduce GFPR during T3, a period in which the fertilized plant increases its tissue production (Table 2).
From T2 to T3 there was an increase in GFPR of 317,435 and $497 \%$ for 30,60 and $90 \mathrm{~kg} /$ ha, respectively. Furthermore, in the absence of fertilization there was a $1169 \%$ decrease in GFPR. Therefore, it appears that fertilization positively affected the GFPR. The third period (46 to 60 days post-germination), referred to as the tiller lifespan, is characterized by the most intensive forage mass production as the plant intensively invests in tissue production. It is noteworthy that the plants significantly decreased their tissue production when fertilization was not performed, especially during T3. This may be related to the low endogenous $\mathrm{N}$ concentration in the plant, as $\mathrm{N}$ was not replaced in the soil, which limited production.

The nitrogen fertilization performed at the beginning of the trial period (15 days postgermination) affected the GFPR (Table 2), which was linearly decreased in the control treatment from T1 to T3. Hence, the fertilization performed during $\mathrm{T} 1$ affected the subsequent periods, due to the increased nitrogen availability in the soil, which contributed to the increase in $\mathrm{N}$ accumulation in the tissues (Table 2). Therefore, nitrogen accumulation by the plant determined the productive vigor during the final trial period (T3; days 46 to 60 post-germination). The GFPR values reported in the current study for the $\mathrm{T} 1$ and $\mathrm{T} 2$ periods are consistent with that reported by Luna et al. (2014), who found increased accumulation, as confirmed by higher leaf appearance rate, foliar and stem elongation rate. In the present study, tiller density resulted in a significant increase in GFPR during the third trial period.

\section{Conclusion}

Based on the agronomic efficiency, $\mathrm{N}$ recovery and $\mathrm{N}$ accumulation in the tissues, the $\mathrm{N}$ concentration of $90 \mathrm{~kg}$ of N/ha was found to be the most suitable during the establishment period of Mombasa grass. 


\section{Acknowledgments}

For the Public Notice: 047/2012 Pro-Amazon: biodiversity and sustainability/CAPES. The Support Program for Excellence Centers/PRONEX/SECT/ National Council for Scientific and Technological Development (CNPq). These projects have supported the research. The authors thank the $\mathrm{CNPq}$ for the Research Productivity Grant.

\section{References}

ALEXANDRINO, E.; VAZ, R. G. M. V.; SANTOS, A. C. Características da Brachiaria Brizantha vc. Marandu durante o seu estabelecimento submetida a diferentes doses de nitrogênio. Bioscience. Journal, Uberlândia, v. 26, n. 6, p. 886-893, 2010.

CABEZAS, A. R. L. Manejo de gramíneas cultivadas em forma exclusiva e consorciada com brachiaria ruziziensis e eficiência do nitrogênio aplicado em cobertura. Revista Brasileira de Milho e Sorgo, Sete Lagoas, v. 10, n. 2, p. 130-145, 2011.

CALOT, M. C.; GUERRI, J.; LEGAZ, F.; CULIÁÑEZ, F.; TADEO, J. L.; PRIMOMILLO, E. Seasonal changes in nitrogen and protein content in organs of Valencia Late (C. sinensis (L.) Osbeck), young trees. Proceedings of the International Society of Citriculture, Riverside, v. 1, n. 5, p. 233-240, 1984.

CANTO, M. W.; HOESCHL, A. R.; BONA FILHO, B.; MORAIS, A.; GASPARINO, E. Características do pasto e eficiência agronômica de nitrogênio em capim-tanzânia sob pastejo contínuo, adubado com doses de nitrogênio. Ciência Rural, Santa Maria, v. 34, n. 4, p. 682-688, 2013.

CASTAGNARA, D. D.; ZOZ, T.; KRUTZMANN, A.; UHLEIN, A.; MESQUITA, E. E.; NERES, M. A.; OLIVEIRA, P. S. R. Produção de forragem, características estruturais e eficiência de utilização do nitrogênio em forrageiras tropicais sob adubação nitrogenada. Semina: Ciências Agrárias, Londrina, v. 32, n. 4, p. 1637-1648, 2011.
ESPINDULA, M. C.; ROCHA, V. S.; SOUZA, M. A. de; GROSSI, J. A. S.; SOUZA, L. T. de. Doses e formas de aplicação de nitrogênio no desenvolvimento e produção da cultura do trigo. Revista Ciência Agrotecnologia, Lavras, v. 34, n. 6, p. 1404-1411, 2010.

FAGERIA, N. K. Otimização da eficiência nutricional na produção das culturas. Revista Brasileira Engenharia. Agrícola Ambiental, Campina Grande, v. 2, n. 1, p. 6-16, 1998.

GUELFI-SILVA, D. R.; COSTA, K. A. de P.; FAQUIN, V.; OLIVEIRA, I. P. de; SOUZA, M. R. F. de; SOUZA, M. A. S. Eficiência nutricional e aproveitamento do nitrogênio pelo capim-Marandu de pastagem em estágio moderado de degradação sob doses e fontes de nitrogênio. Revista Ciência Agrotecnica, Lavras, v. 35, n. 2, p. 242249, 2011.

KUYUMJIAN, L. A. Farinha de casco - chifre e sangue como fonte de Nitrogênio para o capim Mombaça. 2014. Tese (Doutorado em Produção Vegetal) - Universidade Federal do Tocantins, Gurupi.

LUNA, A. A.; DIFANTE, G. S.; MONTAGNER, D. B.; EMERENCIANO NETO, J. V.; ARAÚJO, I. M. M.; OLIVEIRA, L. E. C. Características morfogênicas e acúmulo de forragem de gramíneas forrageiras, sob corte. Bioscience. Journal, Uberlândia, v. 30, n. 6, p. 1803-1810, 2014.

MALAVOLTA, E.; VITTI, G. C.; OLIVEIRA, S. A. Avaliação do estado nutricional das plantas: princípios e aplicações. 2. ed. Piracicaba: Potafos, 1997. 319 p.

QUEIROZ, A. C.; SILVA, D. J. Análise de alimentos: métodos químicos e biológicos. Viçosa, MG: Universidade Federal de Viçosa, 2002, 235 p.

SIDDIQI, M. Y.; GLASS, A. D. M. Utilization index: a modified approach to the estimation and comparison of nutrient utilization efficiency in plants. Journal of Plant Nutrition, March, v. 4, n. 3, p. 289-302, 1981.

SILVA, D. R. G.; COSTA, K. A. P.; FAQUIN, V.; OLIVEIRA, I. P.; SOUZA, M. R. F.; SOUZA, M. A. S. Eficiência nutricional e aproveitamento do nitrogênio pelo capim-marandu de pastagem em estágio moderado de degradação sob doses e fontes de nitrogênio. Ciência Agrotecnica, Lavras, v. 35, n. 2, p. 242-249, 2011. 